\title{
The Manifestation of Climate Change is Represented by the Flash Floods in Atoyac De Alvarez Guerrero, Mexico
}

\author{
Zamora Serrano D, ${ }^{1 *}$ Toribio Jiménez S, ${ }^{2}$ Ruvalcaba Ledezma JC, ${ }^{3}$ \\ Toribio Jiménez $\mathrm{J}^{4 *}$ \\ 1,2,4* Laboratorio de Microbiología Molecular y Biotecnología Ambiental. Unidad Académica de \\ Ciencias Químico Biológicas de la Universidad Autónoma de Guerrero. Chilpancingo de los Bravo \\ Guerrero, México. \\ ${ }^{3}$ [ICSa-UAEH] Instituto de Ciencias de la Salud-Universidad Autónoma del Estado de Hidalgo, \\ México. \\ jeiryjimenez2014@gmail.com
}

\begin{abstract}
Absatract: The change climate are manifested in different ways, some regions with extreme droughts, the rise in global temperature, frost, torrential rains affecting not only human life but by modifying the environment. human establishments living close to water bodies, and after there is excessive increase in these water bodies. In the saw of Atoyac the main damages that happened were human losses in the Community of La Pintada to the credit a detachment of a hill and this one collapsed on the houses of the settlers, covering houses and entire families. There were many peoples that remained incommunicado due to destructions on the highway and fall of bridges, agricultural lands dragging for the strong rains as well as losses of cultivation.
\end{abstract}

Keywords: change climate, flash floods, global temperature, Community of La Pintada, environment

\section{INTRODUCTION}

In recent years, the human being has been concerned about the disruption and irreversible damage that has conditions in nature, these changes are manifested in different ways, some regions with extreme droughts, the rise in global temperature, frost, and torrential rains affecting not only human life but by modifying the environment and the animal species that interact. ${ }^{1}$

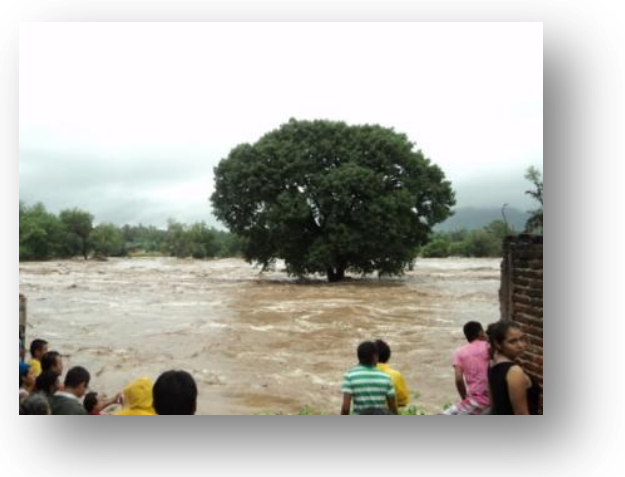

Being the rains some of more torenciales ${ }^{1-5}$ since the human establishments are accentuated close to water bodies, and after there is excessive increase in these water bodies. In the saw of Atoyac the main damages that happened were human losses in the community of the Graffito to the credit a detachment of a hill and this one collapsed on the houses of the settlers, covering houses and entire families.

There were many peoples that remained disqualified due to destructions on the highway and fall of bridges making the step impossible to vehicles and persons. Agricultural lands dragging for the strong rains as well as losses of cultivation ${ }^{6,7,8}$

The fall of the bridge of the Shrimp, bridge Mexcaltepec and loss of arbors to the shore of the river, loss of animals like cattle, horses and pigs. 
In Atoyac de Alvarez lost tabernacles that worked as restaurant where people offered services to the people they were going to recreate the river. Flood of houses that were in the proximity of the river and total loss of the bridge that connects to Atoyac de with the Ticui, similarly there were supply shortage of food and water piped from the torrential rains. All this happened in September, 2013.

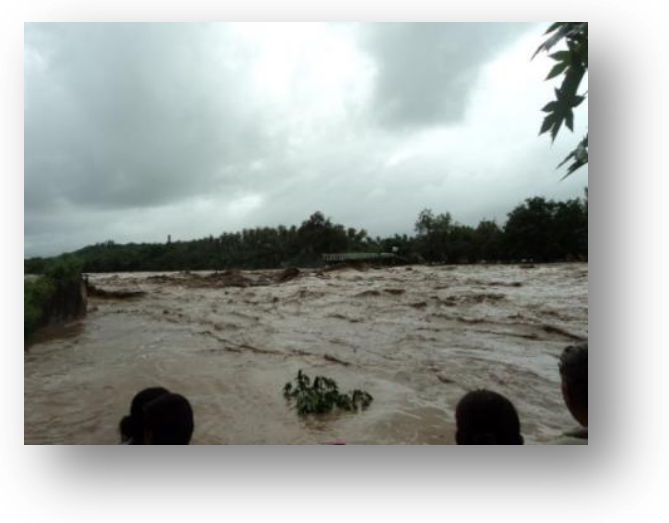

The people in their amazement commented that this had not been seen before, and it is here where the questions are an area of opportunity for something to mitigate the environmental impact by the climate change that each in some way we have generated. What climate change will be the result of poor education to take care of our environment? Do not interact with pedagogical approaches based on the generation of competencies and skills to think about: What is the floods will be increasingly impact? ${ }^{9-12}$

\section{Conclusion}

It is required to interact with pedagogical changes based on the generation of skills and abilities to think and a global commitment to climate change interfere.

\section{ACKNOWLEDGEMENTS}

The authors of the present research article would like to acknowledge and truly thank the collaboration of Laboratorio de Microbiología Molecular y Biotecnología Ambiental, de la Unidad Académica de Ciencias Químico Biológicas; Universidad Autónoma de Guerrero, México. [UAGr0SUPPORT] For the possibility to increase the transferring and modification of scientific knowledge

The authors declare that there is no conflict of interests for the publication of this research paper.

\section{REFERENCES}

[1] Olcina Cantos, J. Panel científico-técnico de seguimiento de la política del agua. Universidad de Alicante Prevención de riesgos: Cambio climático, sequías e inundaciones 1 Panel científicotécnico de seguimiento de la política del agua PREVENCIÓN DE RIESGOS: CAMBIO CLIMÁTICO, SEQUÍAS E INUNDACIONES. Universidad de Alicante, pp 10-240. Consultado 26 de octubre, 2015. Disponible en: http://www.unizar.es/fnca/varios/panel/61.pdf

[2] By Matt McGrath. Climate change to boost summer flash floods, says study. BBC News. Science \& Environment, 01 june, 2014. http://www.bbc.com/news/science-environment27624478

[3] By Roger Harrabin. Society 'to be hit by climate change'. BBC News. Science \& Environment, 16 november 2015. http://www.bbc.com/news/science-environment-34800829

[4] ${ }^{4}$ Remeen Firoz.The true face of climate change. Dhaka Tribune. 11 august. 2015. http://www.dhakatribune.com/op-ed/2015/aug/11/true-face-climate-change

[5] Helmer, Madeleen, and Dorothea Hilhorst. 2006. Natural Disasters and Climate Change. Disasters30, No.1, 1-4

[6] Vinay K. Pandey, Ajai Mishra, Shashank S Mishra. Climate Change And Mitigation Measures For The Hydrometerological Disaster In Himachal Pradesh, India- In Light Of Dams. International Journal of Scientific \& Technology Research, Volume 4, Issue 01, January 2015. http://www.ijstr.org/final-print/jan2015/Climate-Change-And-Mitigation-Measures-For-TheHydrometerological-Disaster-In-Himachal-Pradesh-India-In-Light-Of-Dams.pdf 
The Manifestation of Climate Change is Represented by the Flash Floods in Atoyac De Alvarez Guerrero, Mexico

[7] Saleemul Huq. The future of international finance for development: Development assistance or climate finance?. November. 2015. http://www.dhakatribune.com/feature/2015/nov/08/futureinternational-finance-development-development-assistance-or-climate-finan

[8] Carolyn Kousky, Margaret Walls, and Ziyan Chu. Flooding and Resilience Valuing. Conservation Investments in a World with Climate Change. December 2013. 1616 P St. NW Washington, DC 20036 202-328-5000. www.rff.org

[9] ICE Case Studies, No. 233. Climate Change, Extreme Weather Events, and Violent Conflict in Pakistan by Carmen Radu, December, 2010. http://www1.american.edu/ted/ice/pakistanflood.html

[10] ICE No. 229-Climate Change Induced Extreme Weather Events \& Sea Level Rise in Bangladesh Leading to Migration and Conflict. http://eagle1.american.edu/ w18785a/Bangladesh.html

[11] Ageta, Y. \& T. Kadota. Predictions of changes of glacier mass balance in the Nepal $36 \mathrm{~K}$. Higuchi Himalaya and Tibetan Plateau: a case study of air temperature increase for three glaciers. Annals of Glaciology, 16, pp. 89-94, 1992.

[12] Kundzewicz ZW, Mata LJ, Arnell NW, Döll P, Kabat P, Jiménez B, Miller KA, Oki T, Sen Z, Shiklomanov IA (2007) Freshwater resources and their management. Climate Change 2007: Impacts, Adaptation and Vulnerability. Contribution of Working Group II to the Fourth Assessment Report of the Intergovernmental Panel on Climate Change, M.L. 47 Parry, O.F. Canziani, J.P. Palutikof, P.J. van der Linden and C.E. Hanson, Eds., Cambridge University Press, Cambridge, UK, 173-210. 